\title{
PEMBUATAN TRAINER BOARD ASTABLE MULTIVIBRATOR (AM) SEBAGAI MEDIA PEMBELAJARAN PENDIDIKAN
}

\author{
Syifaul Fuada \\ Jurusan Teknik Elektro, Option Teknik Mikroelektronika Sekolah Teknik Elektro dan Informatika, \\ Institut Teknologi Bandung (ITB) \\ Corresponding author : syifaulfuada@ students.itb.ac.id
}

\begin{abstract}
Abstrak-Trainer board merupakan suatu pemodelan dalam bentuk benda/objek yang memiliki fungsi sama dengan fenomena nyata, dibuat dengan tujuan untuk meningkatkan kemampuan secara aspek kognitif dan psikomotorik dalam mempelajari suatu pembelajaran berbasis praktik. Penelitian ini bertujuan untuk membuat trainer board yang diharapkan dapat membantu memudahkan peserta didik dalam memahami karakteristik Astable Multivibrator berbasis IC OP-AMP sekaligus sebagai pemenuhan kebutuhan labolatorium. Metode yang digunakan dalam penelitian ini adalah prototyping and assembling dengan beberapa tahap pendekatan yakni: Identifikasi, simulasi, eksperimen percobaan, proses desain/perancangan, fabrikasi dan testing. Hasil penelitian menunjukkan bahwa trainer board yang telah dibuat sesuai dengan teorema.
\end{abstract}

Kata Kunci : Astable Multivibrator, IC OP-AMP, Trainer board

\begin{abstract}
Trainer board is a modelling device approach which has related function or same with real pheneonom, it was designed for upgrading the cognitive and the psychomotoric ability of students in a practical courses understanding and applicating concepts. This research goals is to make a trainer board of Astable Multivibrator oscillator, we hope that this learning tools can help them in facilitate to learn Astable Multivibrator characteristics as well as laboratories insfrastructure need. The method in design and implement this trainer board is prototyping and assembling with several approach steps, i.e. identification; simulation; experiment, design process; fabrication; and finally is testing. The results show that the trainer board which designed is appropriate with the theorem.
\end{abstract}

Keywords : Astable Multivibrator, IC OP-AMP, Trainer board

Copyright $\odot 2016$ JNTE. All rights reserved

\section{PENDAhULUAN}

Astable Multivibrator (AM) merupakan jenis oscilator relaksasi yang dapat menghasilkan square wave signal yang kontinyu tanpa sumber trigger dari luar. Oscilator ini dapat menghasilkan dua keadaan output yakni dari keadaan 0 (Off) ke keadaan 1 (On) secara berulang-ulang dalam frekuensi tertentu, yang mana frekuensi ini ditentukan oleh pengosongan dan pengisian kapasitor. Keadaan tidak stabil ini disebut sebagai free running. Oscillator ini telah banyak diaplikasikan berbagai perancangan sistem pewaktu digital tidak hanya untuk keperluan penelitian akademik saja, melainkan dalam fabrikasi industry (commercial purpose). Berdasarkan studi literatur, fungsi AM adalah sebagai berikut: sebagai pembangkit Pulse Width Modulation (PWM) yang dapat diintegrasikan dengan sensor dalam aplikasi prototype alat kesehatan [1] atau aplikasi animal safety [2], sebagai PWM dalam kendali motor DC [3-4]. Sebagai pembangkit frekuensi untuk aplikasi alat bedah listrik [5] alat pengusir hama/tikus [6] , pembangkit suara untuk aplikasi klakson pada kendaraan, wireless charger [7] sebagai rangkaian tunda waktu, Flanger System [8], sampai aplikasi konfigurasi sitem untuk keperluan luar angkasa [9] dsb.

Materi tentang Astable Multivibrator selalu disajikan dalam pengajaran secara teori, praktikum [10], atau sebagai tugas project [11] baik dari tingkat sekolah vokasi sampai perkuliahan di Universitas/ Politeknik/ Institut di Dunia yang mempunyai jurusan ilmu rumpun elektro baik eksakta maupun kependidikan/keguruan. Umumnya terdapat pada matakuliah instrumentasi industri, op-amp, elektronika analog, elektronika telekomunikasi, sinyal dan sistem atau dikemas dalam matakuliah relevan lainnya. Dalam memahami karakteristik dari astable multivibrator, selain 
memerlukan suatu kemampuan berfikir yang sistematis juga memerlukan suatu alat bantu pengajaran sebagai pemenuhan kebutuhan labolatorium.

Penggunaan media praktikum yang berupa trainer board ini akan membantu memudahkan peserta didik untuk memahami suatu konsep yang secara tidak langsung dapat mewujudkan kegiatan belajar yang melibatkan seluruh aspek yang dimiliki peserta didik melalui aspek kognitif, afektif dan psikomotorik.

Berdasarkan uraian tersebut, maka dapat diidentifikasi perumusan masalah dalam penelitian ini adalah bagaimana membuat, fabrikasi dan uji teknis tentang alat praktikum Astable Multivibrator berbasis IC OP-AMP 741 dalam bentuk trainer board untuk tujuan pendidikan. Alat peraga ini terintegrasi dengan produk pengembangan lainnya, yakni Oscillator Wien Bridge [12], Oscillator Colpitts dan Hartley [13] Oscillator Phase shift RC dan telah divalidasi [14].

Media pembelajaran ini masih sangat jarang dikembangkan melalui penelitian R\&D oleh kampus di Indonesia sehingga makalah ini adalah sebuah kebaharuan untuk pengembangan teknologi sejenis dimasa mendatang.

\section{TINJAUAN PUSTAKA}

\subsection{Rangkaian Astable Multivibrator}

Rangkaian AM dapat dibangun dengan menggunakan transistor, IC OP-AMP ataupun IC timer 555. Namun media praktikum ini dibuat menggunakan IC OP-AMP 741. Rangkaian AM yang digunakan dalam pembuatan trainer board ini mengacu pada Gambar 1, rangkaian tersusun oleh feedback dan threshold

Terdapat dua pasang feedback, yakni jaringan R-C pada Vin negatif (-Vin) berfungsi sebagai penentu frekuensi dan dua Resistor pada Vin positif (+Vin) sebagai penentu threshold. Komponen R1 dan R2 merupakan rangkaian pembagi tegangan (Voltage Devider) yang memberi nilai $\mathrm{V}$ referensi $\left(\mathrm{V}_{\mathrm{Ref}}\right)$ pada input non inverting.

$$
\beta=\frac{\mathrm{R} 2}{\mathrm{R} 1+\mathrm{R} 2}
$$

Sedangkan ambang $+\mathrm{V}$ dan $-\mathrm{V}$ ditentukan oleh $\mathrm{R} 1$ dan $\mathrm{R} 2$, dinyatakan dalam rumus:

$$
+\mathrm{V}=\frac{\mathrm{R} 2}{\mathrm{R} 1+\mathrm{R} 2} .(+\mathrm{Vsat})
$$

$$
-\mathrm{V}=\frac{\mathrm{R} 2}{\mathrm{R} 1+\mathrm{R} 2} \cdot(-\mathrm{Vsat})
$$

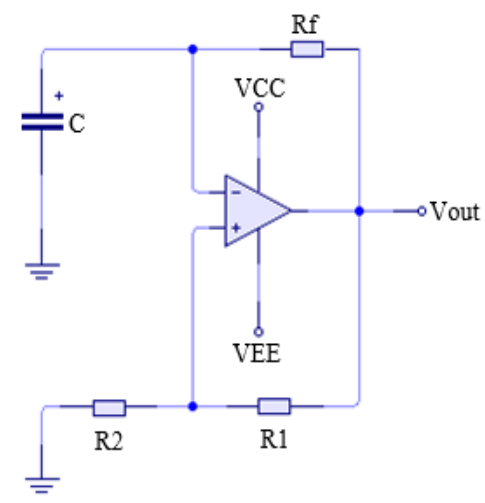

Gambar 1. Rangkaian dasar oscillator jenis Astable Multivibrator (AM)

Cara kerja rangkaian Gambar 1 adalah ketika rangkaian diberi catu daya maka arus akan mengalir dari keluaran Op-Amp menuju Kapasitor melalaui Rf Pada awalnya kapasitor belum bermuatan sehingga tegangannya adalah 0 , arus tersebut membuat kapasitor terisi sehingga tegangannya naik secara perlahanlahan secara eksponensial sampai mencapai Vout. Output Op-amp akan $+\boldsymbol{\beta} \mathrm{V}_{\text {Sat, }}$ dan $\mathrm{V}_{\text {Ref }}$ pada masukan non inverting akan berada pada tegangan ambang positif $+\mathrm{V}_{\text {Treshold }}(+\mathrm{VT})$. Bila tegangan kapasitor melebihi +VT maka keluaran Op-amp akan beralih keadaan yaitu menuju $\boldsymbol{\beta}$ Vsat. Saat ini Vref pada masukan non inverting berada pada tegangan ambang negatif -VT. Sehigga Vref $=\boldsymbol{\beta}$ Vout $=\boldsymbol{\beta}$ Vsat $=$ $\boldsymbol{\beta}$ Vtreshold. Ilustrasi ditunjukkan pada Gambar 2.

Sebaliknya, kini kapasitor mulai mengisi dalam arah yang berlawanan menuju $-\boldsymbol{\beta}$ Vsat. Ketika tegangan kapasitor turun dibawah -VT, maka keluaran op-amp akan kembali pada keadaan semula dan Vout kembali pada $+\boldsymbol{\beta}$ Vsat. Dalam hal ini, satu siklus telah terpenuhi dan akan terus berulang sehingga output akan naik turun secara beraturan. Sedangkan durasi dari $\left(+\boldsymbol{\beta} \mathrm{V}_{\text {Sat }}\right)$ ke saturasi negatif $\left(-\boldsymbol{\beta} \mathrm{V}_{\text {Sat }}\right)$ adalah,

$$
\frac{\mathrm{T}}{2}=\mathrm{RC} \ln \left(\frac{1+\beta}{1-\beta}\right) \operatorname{Sec}
$$

yang mana feedback factor $(\beta)$ mengacu pada persamaan 2, Sehingga apabila $\mathrm{R} 1=\mathrm{R} 2=1 \mathrm{~K} \Omega$ dan $\beta$ akan sama dengan 0.5. Maka persamaan akan dapat disederhanakan menjadi, 
$\mathrm{T}=2 * \mathrm{RC} * \ln \left(\frac{1+0.5}{1-0.5}\right) \mathrm{Sec}$

$\mathrm{T}=2 * \mathrm{RC} *(\ln 3) \operatorname{Sec} ; \ln 3$ atau ${ }^{\mathrm{e}} \log 3=1,09$

$\mathrm{T}=2,19 * \mathrm{RC} \operatorname{Sec}$

Dengan demikian maka frekuensi output dari rangkaian Oscilator Astable Multivibrator adalah:

$$
\mathrm{f}=\frac{1}{\mathrm{~T}}=\frac{1}{2.19 * \mathrm{RC}}
$$

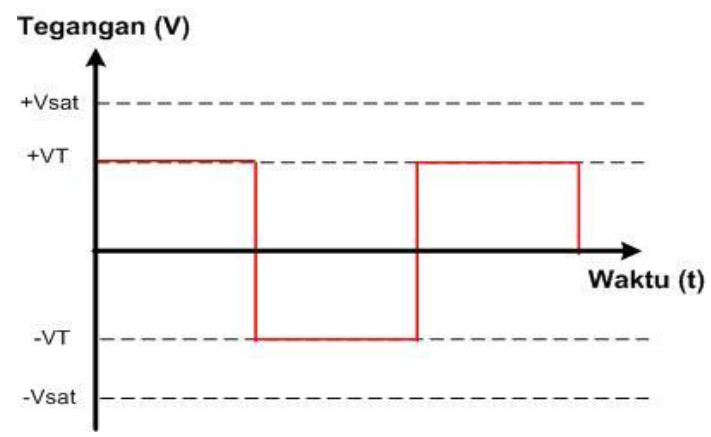

Gambar 2. Prinsip kerja oscillator jenis Astable Multivibrator (AM)

\subsection{IC OP-AMP 741}

Operational Amplifier atau disingkat $O p$ Amp merupakan salah satu komponen analog yang populer digunakan dalam berbagai aplikasi rangkaian elektronika. Aplikasi Op-Amp yang paling sering dibuat antara lain adalah rangkaian inverting, non-inverting, integrator, differensiator, oscilator dll.

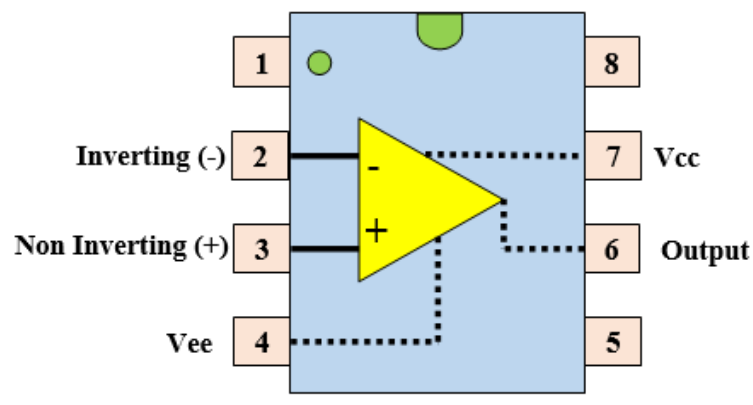

Gambar 3. Pin-pin IC OP-AMP 741

Penulis menggunakan IC OP-AMP general purpose tipe 741 sebagai piranti dalam membangun rangkaian pembangkit gelombang kotak/ Astable Multivibrator. Umpan balik yang digunakan adalah umpan balik negative (negative feedback) atau positif (positive feedback).

Kontruksi intrinsik IC ditunjukkan pada Gambar 3 dan keterangannya ditunjukkan pada Tabel 1.

Tabel 1. Keterangan pin dari IC OP-AMP 741

\begin{tabular}{|c|l|}
\hline Pin Kaki & \multicolumn{1}{|c|}{ Keterangan } \\
\hline $1 \& 5$ & offset null \\
\hline 2 & $\begin{array}{l}\text { masukan membalik / inverting } \\
\text { input (-) }\end{array}$ \\
\hline 3 & $\begin{array}{l}\text { masukan tak membalik / non } \\
\text { inverting input (+) }\end{array}$ \\
\hline 4 & catu tegangan negatif (VEE) \\
\hline 7 & keluaran (output) \\
\hline 7 & catu tegangan positif (VCC) \\
\hline 8 & tidak digunakan \\
\hline
\end{tabular}

\section{METODOLOGI}

\subsection{Gambaran Trainer Board yang akan dibuat}

Beberapa faktor yang menjadi pertimbangan sehingga alat peraga ini harus dibuat di secara self-design adalah:

1. Media serupa diproduksi diluar negeri yang menjadikan harga mahal karena tambahan biaya impor, padahal bahan penyusun media tersedia dipasaran lokal sehingga biaya produksi jauh lebih murah.

2. Terdapat dukungan dana, tenaga (tim PKM \& dosen pembimbing) dan fasilitas labolatorium di Universitas Negeri Malang yang lengkap untuk memproduksi sendiri.

3. Alat peraga yang dilengkapi dengan jobsheet disesuaikan/mengacu pada katalog terbaru, sehingga linier dengan tujuan pembelajaran

4. Media yang dikembangkan melalu R\&D di lingkungan tempat sasaran diklaim lebih memiliki efektifitas dalam jangka waktu yang panjang. Karena melalui beberapa proses i.e: obseravsi kebutuhan media (prapengembangan) dari wawancara dosen pengampu matakuliah dan peserta didik yang menempuh matakuliah yang bersangkutan, validasi desain media sampai ujicoba teknis media dan kelayakannya.

5. Media terverivikasi oleh ahli (media \& materi) yang mencakup tentang keluwesan, kepraktisan, ketahanan media, portable, dan aspek-aspek lain sehingga media benar-benar valid. 
Trainer board Astable Multivibrator yang dikembangkan oleh penulis ini merupakan sebuah alat dimana terdapat beberapa komponen Resistor dan kapasitor yang dirangkai dan dihubungkan ke modul Astable Multivibrator sehingga rangkaian tersebut dapat bekerja sesuai dengan fungsinya (menghasilkan sinyal kotak). Tujuan belajar dari pelaksanaan praktikum astable Multivibrator adalah Peserta didik dapat:

1. mengetahui prinsip kerja dan karakteristik

2. merancang rangkaian $\mathrm{AM}$ secara teori dengan benar.

3. merangkai dan menguji rangkaian AM secara praktik dengan menggunakan alat ukur.

4. menganalisa dan menyimpulkan hasil praktikum AM

Untuk melaksanakan praktikum ini, peserta didik harus memiliki kemampuan awal sehingga diharapkan peserta didik langsung mampu berinteraksi/beradaptasi dengan modul praktikum yang digunakan dan dapat berperan aktif. Kemampuan tersebut adalah peserta didik telah:

1. memahami dasar-dasar fisika instrumentasi dan ilmu matematika

2. mengetahui dan menguasai komponen pasif elektronika seperti resistor, kapasitor, induktor.

3. mengetahui dan menguasai komponen aktif elektronika, dalam hal ini adalah IC OPAMP.

4. mengetahui dan memahami power supply

5. memahami gambar rangkaian elektronika.

6. mengenal berbagai alat ukur seperti multimeter digital atau analog, dan mengoperasikan osciloscope.

\subsection{Flowchart kerja}

Pembuatan trainer board ini dilakukan melalui beberapa langkah, yakni: Identifikasi, (2) simulasi, (3) eksperimen percobaan, (4) proses desain/perancangan, (5) fabrikasi dan (6) testing. Proses identifikasi terdiri dari: penentuan nilai $\mathrm{RC}$ yang digunakan dalam modul dan memasukkan nilai-nilai RC yang telah dipilih dalam persamaan 5, Proses simulasi dengan pendekatan berbasis software menggunakan LTSpice IV untuk memastikan frekuensi yang dihasilkan sesuai dengan persamaan matematis atau belum (hasil komparasi simulasi menggunakan berbagai software disampaikan dalam makalah lain [15]).

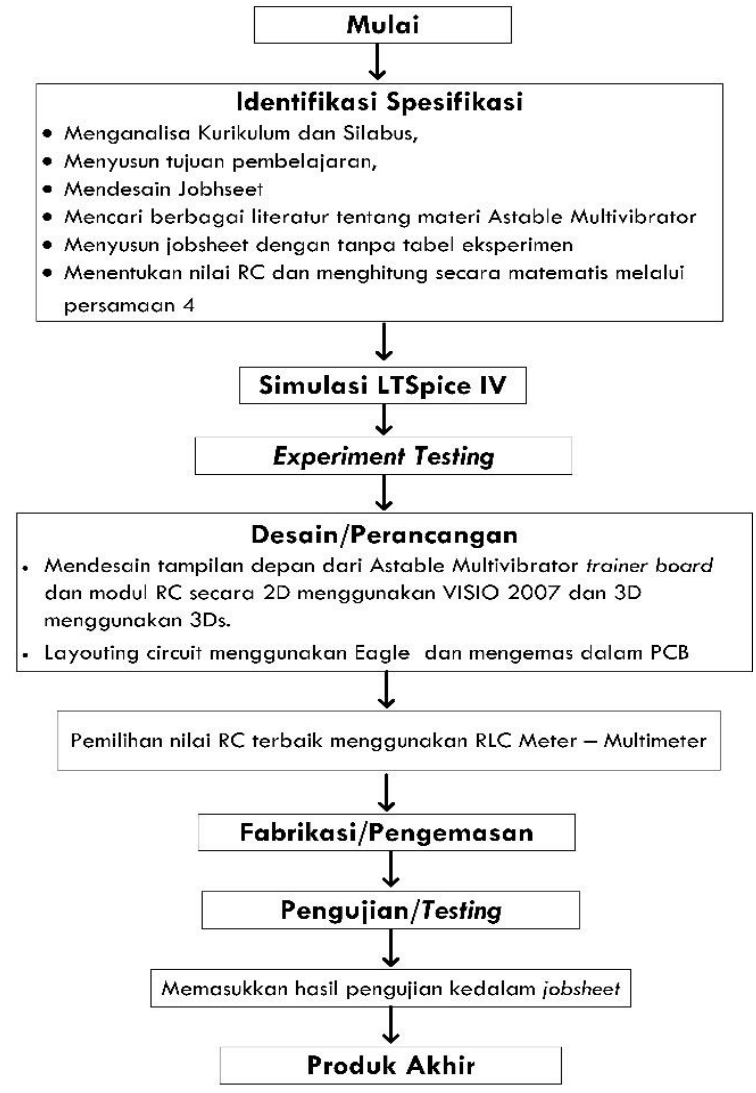

Gambar 4. Metode pendekatan desain dan implementasi trainer board Astable Multivibrator

Selanjutnya adalah pembuktian hitungan dengan melakukan eksperimen pada project board dan menganalisa menggunakan alat ukur osciloskop dan frequency counter. Desain dan perancangan dengan cara memodelkan casing dari trainer board secara 2D dan 3D, melakukan layout PCB dan pabrikasinya. Selanjutnya adalah mengemas dalam board melalui kegiatan mekanik dan soldering dan terakhir adalah menguji secara teknis, hasilnya dimasukkan kedalam tabel praktikum pada jobsheet. Sebelum pengemasan, pemilihan nilai $\mathrm{R}$ dan $\mathrm{C}$ telah diukur terlebih dahulu menggunakan RLC meter karena terkadang kapasitor sudah rusak/tidak dapat bekerja secara maksimal sehingga pengosongan dan pengisian pada kapasitor tidak sempurna. Penulis menggunakan kapasitor dan resistor yang baru, jenis tantalum dan metal film. Flowchart kerja ditunjukkan pada Gambar 4. Penulis melakukan checklist disetiap tahap dan melakukan evaluasi agar mendapatkan hasil produk media praktikum yang baik. 


\section{HASIL DAN PEMBAHASAN}

\subsection{Hasil Produk}

Modul RC ditunjukkan pada Gambar 5 dengan dimensi $28 \mathrm{~cm} \times 10 \mathrm{~cm}$ dan dimensi dari AM adalah $28 \mathrm{~cm}$ x $20 \mathrm{~cm}$. Modul kapasitor berfungsi sebagai kit yang menyediakan nilai fix kapasitor $10 \mathrm{nF}, 100 \mathrm{nF}, 1 \mathrm{uF}, 10 \mathrm{nF}, 100 \mathrm{uF}$ and $1000 \mathrm{uF}$ dan modul induktor menyedikan induktor bernilai $4,39 \mathrm{mH}$ and $16,67 \mathrm{mH}$.
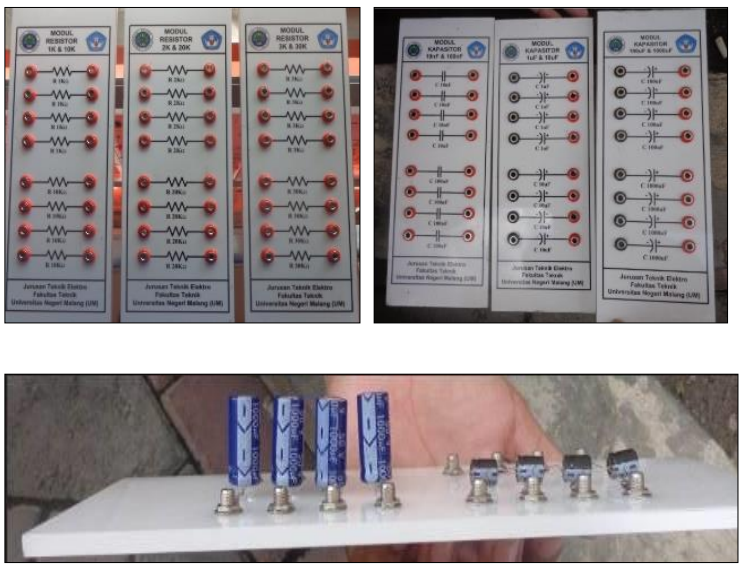

Gambar 5. Modul Resistor dan Kapasitor

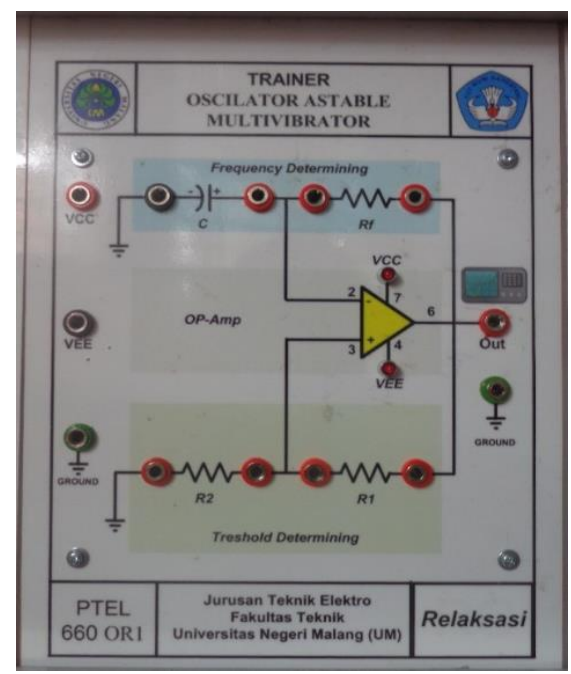

Gambar 6. Trainer board Astable Multivibrator

Terdapat pin-pin banana plug sebagai konektor antar satu komponen dengan trainer board AM melalui kabel jumper. Gambar 7 merupakan PCB satu layer dari rangkaian AM, penulis menggunakan jenis fiber dan dilapisi perak nitrat agar PCB tidak berkarat/berjamur sehingga dapat bertahan lama. Gambar 8 merupakan indicator dari VCC dan VEE menggunakan lampu LED ukuran $3 \mathrm{~mm}$ dan resistor $1 / 4 \mathrm{~W}$, sehingga apabila disambungkan ke power supply maka kedua LED akan menyala Detail spesifikasi trainer board yang dihasilkan ditampilkan pada Tabel 2.

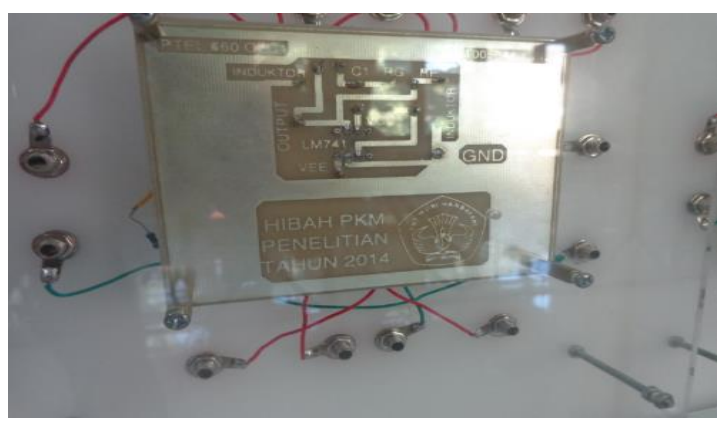

Gambar 7. PCB rangkaian Astable Multivibrator

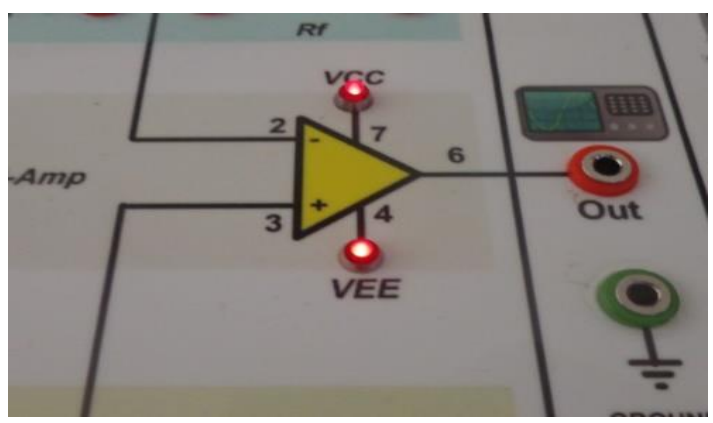

Gambar 8. Indikator $+12 \mathrm{~V}$ dan $-12 \mathrm{~V}$ pada Astable Multivibrator

Tabel 2. Spesifikasi trainer board AM

\begin{tabular}{|c|c|}
\hline Variabel & Deskripsi \\
\hline Kuantitas produk & $\begin{array}{ll}\text { - } & \text { Alat peraga Astable } \\
& \text { Multivibrator (1 kit) } \\
\text { - } & \text { Modul R } 1 \mathrm{~K} \Omega \text { \& } 10 \mathrm{~K} \Omega \text { (1 kit) } \\
\text { - } & \text { Modul R } 2 \mathrm{~K} \Omega \& 20 \mathrm{~K} \Omega \text { (1 kit) } \\
\text { - } & \text { Modul R } 3 \mathrm{~K} \Omega \& 30 \mathrm{~K} \Omega \text { (1 kit) } \\
\text { - } & \text { Modul C } 10 \mathrm{nF} \& 100 \mathrm{nF} \text { (1 kit) } \\
\text { - } & \text { Modul C } 1 \mathrm{uF} \& 10 \mathrm{uF} \text { (1 kit) } \\
\text { - } & \text { Wire/jumper } \\
\end{array}$ \\
\hline IC & IC OP-AMP 741 \\
\hline $\begin{array}{l}\text { Tegangan maks } \\
\text { VCC dan VEE }\end{array}$ & +12 Volt $/-12$ Volt \\
\hline $\begin{array}{l}\text { Warna nyala } \\
\text { LED/ukuran LED } \\
\text { indikator }\end{array}$ & merah / 3mm + LED box \\
\hline $\begin{array}{l}\text { Warna pin banana } \\
\text { plug }\end{array}$ & $\begin{array}{l}\text { VCC : merah; VEE : hitam ; GND } \\
: \text { hijau }\end{array}$ \\
\hline Body & Full Acrylic \\
\hline Sticker & Milk Vynil and Glossy laminating \\
\hline PCB & Fiber PCB with silver screen \\
\hline Spesifikasi Resistor & Fixed Resistor /metalfilm/0,5Watt \\
\hline $\begin{array}{l}\text { Spesifikasi } \\
\text { Kapacitor }\end{array}$ & $\begin{array}{l}\text { Kapasitor Mylar dan electrolit - } \\
\text { tegangan kerja Maks +25V DC }\end{array}$ \\
\hline $\begin{array}{l}\text { Frequency range } \\
\text { available }\end{array}$ & $15 \mathrm{~Hz}$ s.d $46 \mathrm{KHz}$ \\
\hline
\end{tabular}




\subsection{Hasil Uji coba Produk}

Tahap pengujian merupakan tahap akhir dalam perancangan dan pembuatan media praktikum. Berikut merupakan hasil pengujian trainer board AM yang telah dikembangkan, parameter yang dibandingkan adalah perhitungan matematis sesuai persamaan 6 , pengukuran menggunakan oscilloscope dan pengukuran menggunakan frekuensi counter (Tabel 4). Variable R1=R2 = $1 \mathrm{~K} \Omega$. Sampel pengujian ditunjukkan pada Gambar 9 dan 10 dengan variabel $\mathrm{Rf}=20 \mathrm{~K} \Omega, \mathrm{C}=100 \mathrm{nF}$.

Tabel 3. Hasil pengujian teknis dari trainer board-Bagian I

\begin{tabular}{|c|c|c|c|}
\hline \multirow{2}{*}{ No } & \multicolumn{2}{|c|}{$\begin{array}{c}\text { Komponen Modul } \\
\text { RC }\end{array}$} & \multirow{2}{*}{$\begin{array}{c}\text { Perhitungan Teori } \\
\text { (frequency) }\end{array}$} \\
\cline { 2 - 3 } & $\mathrm{Rf}$ & $\mathrm{C}$ & \\
\hline 1 & $2 \mathrm{~K}$ & $1 \mu \mathrm{F}$ & $227,52 \mathrm{~Hz}$ \\
\hline 2 & $2 \mathrm{~K}$ & $10 \mu \mathrm{F}$ & $22,75 \mathrm{~Hz}$ \\
\hline 3 & $3 \mathrm{~K}$ & $100 \mathrm{nF}$ & $1,52 \mathrm{KHz}$ \\
\hline 4 & $3 \mathrm{~K}$ & $1 \mu \mathrm{F}$ & $151,68 \mathrm{~Hz}$ \\
\hline 5 & $10 \mathrm{~K}$ & $10 \mathrm{nF}$ & $4,550 \mathrm{KHz}$ \\
\hline 6 & $10 \mathrm{~K}$ & $100 \mathrm{nF}$ & $455,04 \mathrm{~Hz}$ \\
\hline 7 & $20 \mathrm{~K}$ & $10 \mathrm{nF}$ & $2,275 \mathrm{KHz}$ \\
\hline 8 & $20 \mathrm{~K}$ & $100 \mathrm{nF}$ & $227,5 \mathrm{~Hz}$ \\
\hline 9 & $30 \mathrm{~K}$ & $10 \mathrm{nF}$ & $1,516 \mathrm{KHz}$ \\
\hline 10 & $30 \mathrm{~K}$ & $100 \mathrm{nF}$ & $151,6 \mathrm{~Hz}$ \\
\hline
\end{tabular}

Tabel 4. Hasil pengujian teknis dari trainer board-Bagian II

\begin{tabular}{|c|c|c|c|}
\hline \multicolumn{2}{|c|}{ Oscilloscope } & \multicolumn{2}{c|}{ Frequency Counter } \\
\hline Freq & Time & Freq & Time \\
\hline $200 \mathrm{~Hz}$ & $5 \mathrm{~ms}$ & $196,91 \mathrm{~Hz}$ & $5,078 \mathrm{~ms}$ \\
\hline $21,5 \mathrm{~Hz}$ & $46,3 \mathrm{~ms}$ & $21,55 \mathrm{~Hz}$ & $46,3 \mathrm{~ms}$ \\
\hline $1,351 \mathrm{KHz}$ & $0,74 \mathrm{~ms}$ & $1,349 \mathrm{KHz}$ & $0,7408 \mathrm{~ms}$ \\
\hline $138,8 \mathrm{~Hz}$ & $7,2 \mathrm{~ms}$ & $135,1 \mathrm{~Hz}$ & $7,39 \mathrm{~ms}$ \\
\hline $3,703 \mathrm{KHz}$ & $0,27 \mathrm{~ms}$ & $3,74 \mathrm{KHz}$ & $0,2671 \mathrm{~ms}$ \\
\hline $444,4 \mathrm{~Hz}$ & $2,25 \mathrm{~ms}$ & $448 \mathrm{~Hz}$ & $2,23 \mathrm{~ms}$ \\
\hline $2 \mathrm{KHz}$ & $0,5 \mathrm{~ms}$ & $2,01 \mathrm{KHz}$ & $0,4955 \mathrm{~ms}$ \\
\hline $227,2 \mathrm{~Hz}$ & $4,4 \mathrm{~ms}$ & $227,5 \mathrm{~Hz}$ & $4,39 \mathrm{~ms}$ \\
\hline $1,388 \mathrm{KHz}$ & $0,72 \mathrm{~ms}$ & $1,38 \mathrm{KHz}$ & 0,7205 \\
\hline $156,25 \mathrm{~Hz}$ & $6,4 \mathrm{~ms}$ & $153,1 \mathrm{~Hz}$ & $6,52 \mathrm{~ms}$ \\
\hline
\end{tabular}

Prosedur yang dilakukan adalah persis seperti pelaksanaan praktikum, yakni menyambungkan modul $\mathrm{R}$ dan $\mathrm{C}$ ke board Astable Multivibrator menggunakan jumper. Output board disambungkan ke alat ukur.
Instrument-instrumen yang digunakan antara lain: alat ukur (Digital AVO meter, Oscilloscope, frequency counter); modul Resistor dan modul kapasitor; power supply simetris $(+\mathrm{V}, \mathrm{GND},-\mathrm{V})$; jumper and tabel pengukuran.

Pada data hasil terdapat selisih baik secara perhitungan teoretik, hasil pengukuran menggunakan osciloskop maupun frequency counter. Nilai sebenarnya ditunjukkan pada frequency counter, karena ketelitian osciloskop hanya mencapai 0,2 atau $1 / 5$. Sedangkan frequency counter memiliki ketelitian hingga 0,00001 atau $1 / 10^{5}$.

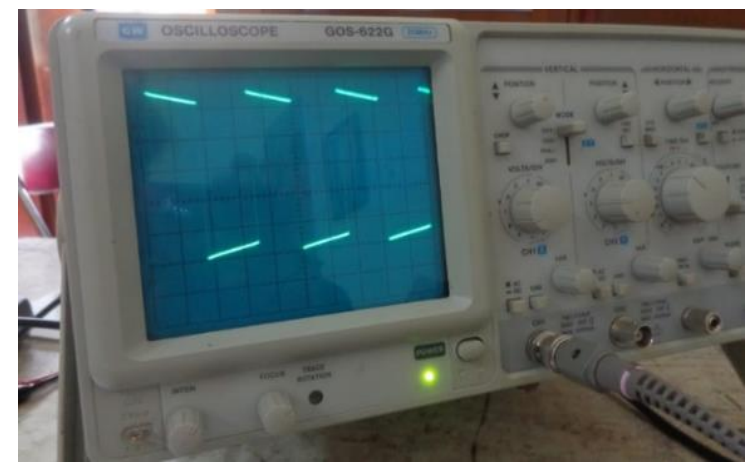

Gambar 9. $f_{0}$ dari trainer board Astable Multivibator pada alat ukur Osciloscope

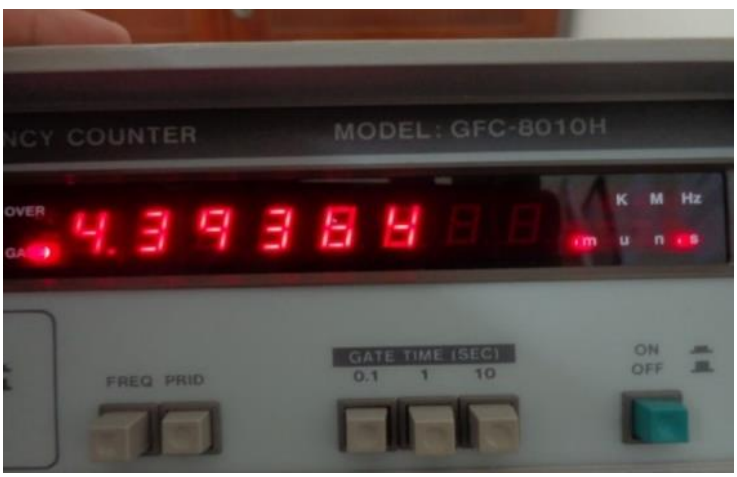

Gambar 10. Frekuensi output dari trainer board Astable Multivibator pada alat ukur frequency counter

Berdasarkan praktikum, didapat data sebagai berikut: nilai simpangan terjauh, yakni pada pengujian nomor 3,7 dan 9. Pengujian dengan variable no. 6, merupakan hasil yang paling bagus. Selain mempunyai selisih yang sedikit, sinyal output yang ditampilkan oleh osciloskop juga bagus. Secara keseluruhan 
terdapat selisih, namun tidak terlalu jauh simpangannya Perbedaan frekuensi ini karena faktor komponen pasif pada rangkaian oscilator yakni pada Resistor dan kapasitor.

Umumnya bila menggunakan komponen yang Second hand sulit menemukan hasil yang sempurna. Sedangkan perbedaan ampitudo disebabkan oleh kapasitor yang digunakan, semakin besar nilainya maka sinyal semakin cacat. Karena waktu antara pengisian dan pengosongan jeda waktu yang lama, sehingga menyebabkan cacat sinyal (Overshoot).

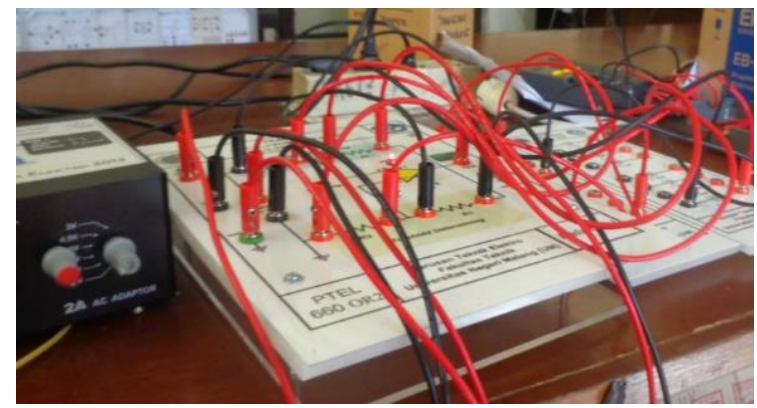

Gambar 11. Proses wiring dari trainer board Astable Multivibator

Berdasarkan langkah-langkah yang ditempuh dimulai dari perencanaan sampai pengujian dapat dikatakan bahwa trainer board Astable Multivibrator telah sesuai dengan perhitungan matematis (persamaan 6). Untuk dapat digunakan sebagai media bantu dalam proses pengajaran diperlukan proses validasi ahli dan uji coba ke mahasiswa praktikan seperti yang ditunjukkan pada Gambar 12.

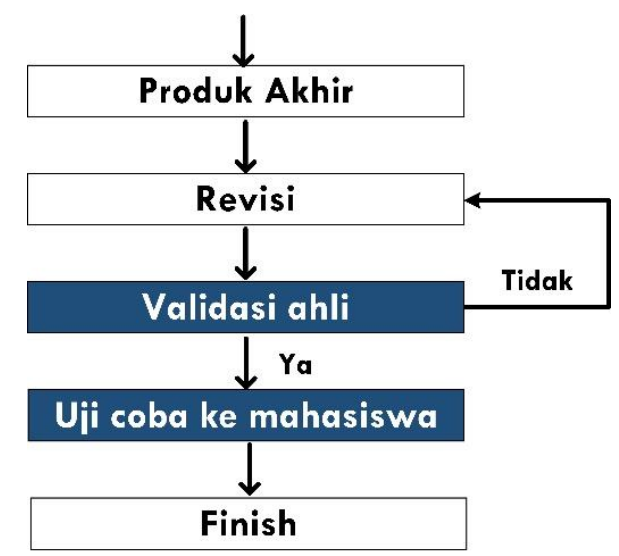

Gambar 12. Metode pendekatan desain dan implementasi trainer board Astable Multivibrator lanjutan

\section{KESIMPULAN}

Kegiatan pembelajaran berbasis praktikum merupakan suatu aktivitas untuk membuktikan kebenaran dari suatu teori yang disampaikan oleh dosen/guru dalam kegiatan pembelajaran. Trainer board dibuat sebagai media ajar yang efektif untuk membantu meningkatkan kemampuan motorik peserta didik dalam mempelajari Astable Multivibrator, selain itu juga membangun kemampuan peserta didik untuk mampu bekerja dalam kelompok.

Penulis telah berhasil dalam membuat, fabrikasi dan uji teknis tentang alat praktikum Astable Multivibrator berbasis IC OP-AMP 741 dalam bentuk trainer board untuk tujuan pendidikan. Oscilator Astable Multivibrator yang dikembangkan dapat menghasilkan frekuensi dalam bentuk gelombang persegi tanpa input. Frekuensi tersebut diproduksi oleh keadaan "nol" dan "satu" secara kontinyu yang ditentukan oleh nilai Resistor feedback dan kapasitor. Hal ini terbukti pada percobaan ke-1 sampai ke-10, dengan $\mathrm{R}$ dan $\mathrm{C}$ yang berbeda maka frekuensi berbeda pula.

Saran untuk pemakaian nilai RC agar frekuensi yang dihasilkan baik, hendaknya menggunakan Resistor dengan toleransi minimum $1 \%$ yakni dari jenis metal film dan kapasitor tantalum. Diperlukan tambahan trainer board astable multivibrator berbasis transistor dan IC 555 sehingga media ajar lebih bervariasi.

\section{UCAPAN TERIMAKASIH}

Penelitian ini didanai oleh Kementerian Riset-Teknologi dan Pendidikan Tinggi Republik Indonesi" melalui Program Kreativitas Mahasiswa bidang Penelitian (PKMP) No 0263/E5/2014 tentang "Penetapan Penerima Hibah Penelitian, Program Pengabdian kepada Masyarakat, Program Kreativitas Mahasiswa Tahun Anggaran 2014”. Penelitian ini dilakukan di Jurusan Teknik Elektro Universitas Negeri Malang (UM) dan telah digunakan sebagai bagian dari pembelajaran praktikum oleh dosen pengampu matakuliah workshop instrumentasi industri, penulis mengucapkan terimakasih kepada bpk Hakkun dan bpk. Suwasono sebagai supervise dalam projek ini. 


\section{DAFTAR PUSTAKA}

[1] Aakash S. S., K. Ganesan and Ashwin R., "Smart Pill Box," Indian Journal of Science and Technology, Vol. 8(2), pp. 189-194, January 2015.

[2] Vijayaraghavan S., Vijayalakshmi T. G., Swathi V., "Ultrasonic Sensor Animal Safety System," Proc. of IEEE Int. Conf. on Recent Advances and Innovations in Engineering (ICRAIE-2014), pp. 1-2, May 2014.

[3] M. Taufiq T., Arif J. T., "Fan Controlling Based On Inverter Technology," Techno, Vol. 13(1), pp. 52-56, April 2012.

[4] Animesh G., Urmila T., "PWM Based Speed Control of DC Motor," Int. Journal of Advanced Scientific and Technical Research, Vol.1(3), pp. 648-658, 2013

[5] T. Firmansyah, R. Alfanz, W. B. Suwandidan, "Rancang Bangun Low Power Elektric Surgery (Pisau Bedah Listrik) pada Frekuensi $10 \mathrm{KHz}$," Jurnal Nasional Teknik Elektro (JNTE), Vol. 5(1), pp. 118-127, Maret 2016.

[6] Phila D, Bidayatul A., Wira B.H., "Rancang Bangun Alat Elektronik Pengusir Hama Tikus pada Rumah Tangga.", 2008, Tersedia di: http://repository.unhas.ac.id/handle/1234 56789/4258/.

[7] 7. S. P. Rahman, M. Sarwoko, Zulfi, "Perancangan dan Realisasi Prototype Sistem Transfer Daya Listrik Nirkabel untuk Mengisi Baterai Handphone", Jurnal Nasional Teknik Elektro (JNTE), Vol. 2(2), pp. 35-38, September 2013.

[8] M.H.W. Budhiantho, G. Dewantoro, D. Sabatino, "Perancangan Penguat Awal Menggunakan Tabung Hampa Pada Aras Tegangan Rendah", Jurnal Nasional Teknik Elektro (JNTE), Vol. 4, (1), Pp. 2229, Maret 2015

[9] L. Pîslaru D., A.M. Morega, "Electronic Drive System of a Linear Magnetostrictive Motor Designed for Outer Space Applications," Proc. of The $9^{\text {th }}$ Int. Symposium on Advanced Topics in Electrical Engineering, pp. 225-230, May 2015.

[10] Rajender K., Krishan K, "PSPICE and MATLAB / SimElectronic Based Teaching of Linear Integrated Circuit: A
New Approach," Int. Journal of Electronics and Electrical Engineering, Vol. 3(1), pp. 34-37, February 2015.

[11] Luis B. O., Nuno P. and Nuno P., "The design of a Light Barrier System as an Undergraduate Laboratory Project," Proc. of Int. Symposium on Circuits and Systems (ISCAS), pp. 2425-2428, June 2014.

[12] S. Fuada, Pengujian Trainer Oscilator Wien Bridge dengan Menggunakan Osciloskop dan Frekuensi Counter. Prosiding Seminar Nasional Teknologi Informasi dan Aplikasinya, Vol.6, pp. A32-A36, Juni 2015.

[13] S. Fuada, H. Elmunsyah, Suwasono, "Design and Fabrication of LC-Oscillator Tool Kits Based Op-Amp for Engineering Education Purpose," TELKOMNIKA Indonesian Journal of Electrical Engineering, Vol. 17(1), pp. 88-100, January 2016.

[14] S. Fuada., "Pengujian Validitas Alat Peraga Pembangkit Sinyal (Oscillator) untuk Pembelajaran Workshop Instrumentasi Industri”. Prosiding Seminar Nasional Pendidikan (SEMNASDIK), pp.854-861, November 2015.

[15] S. Fuada, and F.T. Aquari, "Square wave generator circuit analysis using matlab approach," Int. Journal of Engineering Sciences and Research Technology, Vol.2(2), pp. 371-382, February 2013

\section{Biodata Penulis}

Syifaul Fuada, menamatkan S1 di Jurusan Teknik Elektro Fakultas Teknik Universitas Negeri Malang tahun 2014. Saat ini sedang menempuh studi pascasarjana di Jurusan Teknik Mikroelektronika Institut Teknologi Bandung melalui beasiswa Panasonic Scholarship. Beberapa penghargaan yang pernah diraih yakni: Finalis PIMNAS XXVII 2014 di UNDIP, Finalis Lomba Cipta Teknologi TNI AD 2014, The Best poster dalam SPRINT LIPI 2014, The Best poster di KIPNAS LIPI XI 2015 dan salah satu dari 106 Innovator Indonesia tahun 2014 oleh BIC KEMRISTEK DIKTI. Telah mendapatkan dua paten terdaftar yakni Robogas dan Helmet Charger dari LPPM UM. 